\title{
„EGO LIBRARISTA”. DZIAŁALNOŚĆ JANA ZE SKAWINY JAKO BIBLIOTEKARZA NA WYDZIALE PRAWA UNIWERSYTETU KRAKOWSKIEGO
}

\section{Streszczenie}

Artykuł poświęcony jest osobie Jana ze Skawiny (†1520), doktora i profesora prawa kanonicznego, bibliotekarza biblioteki Wydziału Prawa Uniwersytetu Krakowskiego. Nie należał on wprawdzie do postaci pierwszoplanowych lub wyróżniających się spośród grona uczonych polskich przełomu XV i XVI stulecia, nie zachowała się także jego spuścizna naukowa, niemniej jednak jako opiekun księgozbioru bibliotecznego wykazał się szczególną gorliwością na tle innych profesorów sprawujących funkcję bibliotekarza. W latach 1501-1515 pozyskał na rzecz biblioteki wydziałowej i usystematyzował wiele dzieł o tematyce prawniczej lub kaznodziejskiej, mających służyć jako pomoc dla profesorów i studentów prawa. Z perspektywy czasu nieocenionym dokonaniem krakowskiego uczonego było umieszczenie not wskazujących na przynależność rękopisów do księgozbioru Kolegium Prawniczego. Pozwalają one nie tylko na jednoznaczne przypisanie kodeksów do biblioteki Collegium Iuridicum, ale też informują o poprzednich właścicielach oraz o sposobie i dacie pozyskania danego egzemplarza. Spośród 46 zachowanych do dzisiaj średniowiecznych ksiąg Wydziału Prawa aż 39 posiada noty wpisane jego ręką.

Jan ze Skawiny był nie tylko opiekunem książek, ale także darczyńcą kilkunastu rękopisów. Dzięki jego zabiegom kilku profesorów prawa oraz członków rodziny Jana przekazało w testamencie swoje księgozbiory na rzecz Wydziału Prawa. W obliczu tragicznego w skutkach pożaru gmachu Collegium Iuridicum w 1455 roku działania Jana ze Skawiny na rzecz pozyskania nowych dzieł pozwoliły na częściowe odbudowanie biblioteki jurystów. Były to dzieła przede wszystkim prawnicze, a także teologiczne, które mogły służyć jako pomoc w pracy kaznodziejskiej. Pobieżny przegląd dzieł znajdujących się w księgozbiorze Wydziału Prawa pozwala na stwierdzenie, że dobór pism pozyskanych lub ofiarowanych przez Skawińskiego nie był przypadkowy.

* Wojciech Świeboda - dr historii; adiunkt w Sekcji Rękopisów Biblioteki Jagiellońskiej w Krakowie; e-mail: woj.swieboda@uj.edu.pl

https://orcid.org/0000-0002-5265-5784 
Na pozór skromne świadectwa działalności Jana ze Skawiny na funkcji bibliotekarza okazują się być nieocenione dla poznania zasobu i organizacji biblioteki Kolegium Prawniczego. Noty, które zamieścił on w rękopisach, stanowią niezwykle ważne źródło informacji o średniowiecznym Wydziale Prawa Uniwersytetu Krakowskiego. Dowodzą również, że stanowisko bibliotekarza nie musiało być traktowane przez profesorów uniwersyteckich jako obciążenie, ale mogło być postrzegane jako rodzaj wyróżnienia. Jan ze Skawiny piastował szereg ważnych stanowisk kościelnych i uniwersyteckich, a jednak pisał o sobie skromnie, ale z dumą - „librarista”.

Słowa kluczowe: Jan ze Skawiny; Uniwersytet Krakowski; Wydział Prawa; biblioteka; rękopisy średniowieczne

\section{Biblioteka uniwersytecka w średniowiecznym systemie nauczania}

Biblioteki uniwersyteckie stanowily nierozerwalny element każdej uczelni, książki zaś od czasów średniowiecznych zajmowały ważne miejsce w systemie nauczania. Proces tworzenia się księgozbiorów i udostępniania ich profesorom i studentom na początkowym etapie w zasadzie nie wymagał podejmowania żadnych czynności formalno-prawnych. Wraz z rozpoczęciem pierwszych wykładów wśród profesorów i studentów w sposób naturalny rozpoczynał się obieg książek, początkowo rękopiśmiennych, a od drugiej połowy XV wieku także drukowanych. Rękopisy z różnymi dziełami będące pomocą naukową i dydaktyczną stanowiły wprawdzie własność nauczających, jednak ci na ogół bez przeszkód udostępniali je innym członkom uniwersytetu. Taki model tworzenia się biblioteki uniwersyteckiej był typowy dla większości szkół w Europie w okresie średniowiecza, w tym także Uniwersytetu Krakowskiego, jakkolwiek trzeba przyznać, że przebieg i znaczenie samego procesu pozostają trudno uchwytne ${ }^{1}$.

W ciągu dwóch pierwszych dekad funkcjonowania uczelni krakowskiej ufundowanej w 1400 roku przez króla Władysława Jagiełłę zwyczajem stało się, że aktywni zawodowo profesorowie u schyłku życia całe swoje księgozbiory bądź ich części ofiarowywali lub zapisywali w testamencie uniwersytetowi lub wydziałowi, na którym wykładali ${ }^{2}$. Najstarszy taki zapis znany jest z 1410 roku, w którym doktor teologii Jan Isner polecił przekazać po swojej śmierci wszystkie należące do niego książki o tematyce teologicznej i filozoficznej na rzecz Kolegium króla Władysława (czyli późniejszego Collegium Maius) oraz Bursy Ubogich ${ }^{3}$. Dary w postaci pojedynczych kodeksów albo całych spuścizn pisarskich stały się podstawą do utworzenia kilku bibliotek dla studentów poszczególnych wydziałów: Siedmiu Sztuk Wyzwolonych, Teologicznego oraz Prawa. Osobnej biblioteki nie posiadał jedynie Wydział Medyczny, niemniej jednak studenci medycyny mogli

${ }^{1}$ J. Zathey, Biblioteka Jagiellońska w latach 1364-1492, w: Historia Biblioteki Jagiellońskiej, t. 1: 1364-1775, red. I. Zarębski, Kraków 1966, s. 4-5; P.W. Knoll, “A Pearl of Powerful Learning”. The University of Cracow in the Fifteenth Century, Leiden-Boston 2016, s. 595.

2 J. Zathey, Biblioteka Jagiellońska, s. 28-32.

${ }^{3}$ Codex diplomaticus Universitatis Studii Generalis Cracoviensis, t. 1, Cracoviae 1870, s. 8284; W. Szelińska, Biblioteki profesorów Uniwersytetu Krakowskiego w XV i początkach XVI wieku, Wrocław-Warszawa-Kraków 1966, s. 23-28. 
znaleźć potrzebne im podręczniki i pomoce w bibliotekach uniwersyteckich. Nie tylko kolegia, ale także i bursy dysponowały własnymi zbiorami książek. Dopiero na początku XIX wieku rozproszone po różnych budynkach księgozbiory zostały scalone w jedną bibliotekę uniwersytecką, która mieściła się w kamienicy Collegium Maius na ulicy św. Anny w Krakowie ${ }^{4}$.

Społeczność uniwersytecka od samego początku doceniała znaczenie tekstu pisanego w procesie kształcenia i widziała konieczność zachowania dbałości o księgozbiory. Już w 1403 roku w źródłach pojawia się wzmianka o funkcji tzw. opiekuna książek (pater librorum) użyta w stosunku do Macieja z Koła, profesora Wydziału Artium ${ }^{5}$. Kontekst zachowanego dokumentu notarialnego przedstawia sprawę przywłaszczenia przez jednego z pełnomocników uniwersytetu pieniędzy, które miały zostać przeznaczone na zakup lub sporządzenie rękopisó $w^{6}$. $Z$ powyższego źródła da się wydobyć kilka cennych dla dziejów biblioteki informacji: po pierwsze - obieg książek na uniwersytecie był już wówczas powszechny, po drugie - pieczę nad ich wypożyczaniem sprawował powoływany przez społeczność uniwersytecką bibliotekarz, po trzecie - już w pierwszych latach funkcjonowania uniwersytetu jej władze zaczęły świadomie prowadzić politykę pozyskiwania nowych nabytków rękopiśmiennych drogą kupna. Więcej informacji o sposobie kurateli nad księgozbiorem i udostępniania dzieł posiadamy dla okresu późniejszego. W 1429 roku w Statucie Kolegium Króla Władysława zostały ustalone zasady opieki nad książkami stanowiącymi własność uniwersytetu. Corocznie wybieranych było dwóch kustoszy (custodes), którzy mieli dbać o bibliotekę, ustalać zasady wypożyczania i udostępniania książek, a pod koniec kadencji zadbać o zwrot egzemplarzy i zdać sprawozdanie ze stanu liczebnego zbioru? ${ }^{7}$ Ponadto do ich kompetencji należało pozyskiwanie nowych ksiąg oraz wydawanie odpisów dyplomów absolwentom ${ }^{8}$. Ze statutu nie wynika jasno, czy mieli oni zmieniać się co pół roku, jak to miało miejsce w przypadku urzędu rektora (od 1419 roku), czy każdy z nich sprawował pieczę nad inną częścią księgozbioru, a więc pierwszy - kolegium teologów, drugi - kolegium artystów. Bardziej prawdopodobna wydaje się druga hipoteza, ponieważ w XV wieku w Kolegium Króla Władysława istniały dwie biblioteki znajdujące się na różnych piętrach ${ }^{9}$. Opiekunami książek zostawali członkowie kolegium niezależnie od wieku, ale z pewnym już doświadczeniem uniwersyteckim. Nie pobierali z tego tytułu żadnego dodatkowego wynagrodzenia, a ich funkcja nie zwalniała ich z prowadzenia zwyczajowych wykładów. Dopiero w latach 30. XVI wieku profesor pełniący obowiązki bibliotekarza zaczął otrzymywać stałą pensję za opiekę początkowo nad ołtarzem

${ }^{4}$ M. Galos, Ż. Kubic, Biblioteka Jagiellońska w latach 1775-1835, w: Historia Biblioteki Jagiellońskiej, t. 2: 1775-1918, red. P. Lechowski, Kraków 2017, s. 47.

${ }^{5}$ Biblioteka Jagiellońska (dalej: BJ), rkps 2371, k. Ir.

${ }^{6}$ Zathey, Biblioteka Jagiellońska, s. 26.

${ }^{7}$ Statuta antiqua Collegii Majoris, wyd. J. Szujski, w: Archiwum do Dziejów Literatury i Oświaty $w$ Polsce, Seria I, t. 1, Kraków 1878, s. 11-12; Zathey, Biblioteka Jagiellońska, s. 24.

${ }^{8}$ A. Lewicka-Kamińska, Biblioteka Jagiellońska w latach 1492-1655, w: Historia Biblioteki Jagiellońskiej, t. 1, s. 211.

${ }^{9}$ Zathey, Biblioteka Jagiellońska, s. 24; Knoll, “A Pearl of Powerful Learning”, s. 599, 602. 
Poczęcia NMP i św. Zuzanny w kościele św. Anny w Krakowie, a od 1538 roku nad ołtarzem Męki Pańskiej, Bogurodzicy i św. Bartłomieja w kościele NMP. Do jego zadań, poza odprawianiem mszy św. przed wspomnianym ołtarzem, należało codzienne otwieranie biblioteki na co najmniej dwie godziny. Nałożona została również na niego odpowiedzialność finansowa za zniszczenie lub zagubienie egzemplarzy ${ }^{10}$.

\section{Biblioteka średniowiecznego Wydziału Prawa}

Wydział Prawa otrzymał swój gmach w 1403 roku na ul. Grodzkiej dzięki zakupowi kamienicy należącej do Sędziwoja z Szubina, kasztelana kaliskiego, znajdującej się zaraz obok kościoła pw. św. Marii Magdaleny, za pieniądze zapisane $\mathrm{w}$ testamencie przez królową Jadwigę. W kolejnych latach kolegium było powiększane o nowe pomieszczenia dzięki łączeniu sąsiednich kamienic. W 1406 roku od strony północnej pozyskano budynek od braci Mikołaja i Niemierzy z Irządz, w 1451 roku zaś doktor prawa i oficjał krakowski Jan Elgot przyłączył swój dom graniczący od strony południowej. Cały kompleks nazywany Collegium Iuridicum do 1450 roku służył wykładowcom i studentom prawa oraz medycyny, a w późniejszym czasie już tylko wyłącznie tym pierwszym ${ }^{11}$. Mimo znacznego oddalenia gmachu od pozostałych budynków uczelni nigdy nie doszło do oddzielenia fakultetu prawniczego od struktur uniwersyteckich, jak miało to miejsce np. w Bolonii czy Pradze ${ }^{12}$. Kolegium Prawnicze, podobnie jak pozostałe kolegia uniwersyteckie, było nie tylko domem profesorskim i miejscem odbywania wykładów, ale przede wszystkim siedzibą wspólnoty akademickiej posiadającej swój majątek, statuty regulujące jej życie oraz kultywującej własne zwyczaje $^{13}$. W odróżnieniu jednak od wykładowców Wydziałów Siedmiu Sztuk Wyzwolonych i Teologicznego część profesorów prowadzących wykłady z zakresu prawa kanonicznego mieszkała w domach przydzielonych im przez instytucje publiczne lub kościelne, w których pełnili określone funkcje ${ }^{14}$.

Można przypuszczać, że pierwsze księgi rękopiśmienne, które stanowiły zalążek biblioteki Wydziału Prawa, znalazły się w Kolegium wraz z pierwszymi profesorami, którzy w nim zamieszkali ${ }^{15}$. Najstarsza wzmianka potwierdzająca

${ }^{10}$ Zathey, Biblioteka Jagiellońska, s. 25; Lewicka-Kamińska, Biblioteka Jagiellońska, s. 213-216.

${ }^{11}$ A. Włodarek, Architektura średniowiecznych kolegiów i burs Uniwersytetu Krakowskiego, Kraków 2000, s. 30-31, 192-193; M. Szyma, Gmach kolegium prawniczego i Dom Kanoniczny do końca epoki nowożytnej, w: S.A. Sroka i in., Collegium Iuridicum, Kraków 2015, s. 35-43.

12 Z. Kozłowska-Budkowa, Odnowienie jagiellońskie Uniwersytetu Krakowskiego (13901414), w: Dzieje Uniwersytetu Jagiellońskiego, t. 1, s. 71, 76.

${ }^{13}$ Włodarek, Architektura średniowiecznych kolegiów, s. 30-31, 192-193; Szyma, Gmach kolegium prawniczego, s. 35-43; na temat uposażenia poszczególnych katedr Wydziału Prawa zob. L. Ehrlich, Z dziejów Wydziału Prawa UJ w wieku XV, w: Studia z dziejów Wydziatu Prawa Uniwersytetu Jagiellońskiego, red. M. Patkaniowski, Kraków 1964, s. 35-48 („Zeszyty Naukowe Uniwersytetu Jagiellońskiego. Prace Prawnicze", z. 18), s. 38-39.

${ }^{14}$ W. M. Bartel, Dzieje Wydziału Prawa Uniwersytetu Jagiellońskiego przed reforma Kołtatajowska (Próba zarysu), „Krakowskie Studia Prawnicze”, 3 (1970) s. 164.

${ }^{15}$ W. Świeboda, Na tropie średniowiecznych rękopisów Wydziału Prawa Uniwersytetu Kra- 
funkcjonowanie biblioteki Collegium Iuridicum pochodziła z 1446 roku, ale karta z zapiską proweniencyjną rękopisu, gdzie powyższa data miała się pojawić, zaginęła w XIX wieku ${ }^{16}$. Kolejną tym razem potwierdzoną informacją źródłową jest wpis w aktach rektorskich z 1478 roku $^{17}$. O lokalizacji biblioteki dowiadujemy się z kolei z noty w rękopisie Biblioteki Jagiellońskiej o sygnaturze 248. Przez wiele lat znajdowała się ona na parterze skrzydła wschodniego obok izby mieszkalnej i lektorium ${ }^{18}$. Informację tę potwierdziły badania archeologiczne ${ }^{19}$. W połowie XVIII wieku (przed rokiem 1766) księgozbiór został przeniesiony na pierwsze piętro sali południowej i pozostawał tam do końca stulecia, po czym trafił do budynku Bursy Jerozolimskiej, a w końcu w 1812 roku do głównej biblioteki uniwersyteckiej mieszczącej się w Collegium Maius ${ }^{20}$.

Swój największy rozkwit biblioteka przeżywała w XVI wieku, gdy miały miejsce znaczące darowizny i zapisy ze strony profesorów oraz osób spoza kręgu uczonych, szczególnie biskupa krakowskiego Piotra Tomickiego oraz królowej Anny Jagiellonki ${ }^{21}$. Niestety nie jest możliwe oszacowanie liczebności księgozbioru, ponieważ nie zachowała się żadna informacja źródłowa podająca choćby orientacyjną wielkość zasobu, a ponadto większa jego część spłonęła w pożarach Collegium Iuridicum. Pierwszy z nich z roku 1455 zniszczył wszystkie księgi, jakie wówczas znajdowały się $\mathrm{w}$ budynku ${ }^{22}$. Ocalały jedynie pojedyncze egzemplarze, które akurat wtedy były wypożyczone na zewnątrz ${ }^{23}$. Nie wiadomo, czy kolejne pożary miasta z lat 1462 i 1474 wyrządziły jakiekolwiek szkody księgozbiorowi prawników, natomiast $\mathrm{z}$ całą pewnością dużego spustoszenia dokonał żywioł z 1719 roku $^{24}$. Na początku XIX wieku Jerzy Samuel Bandtkie zajmujący

kowskiego, w: Felix indiget amicis. Studia z dziejów kultury duchowej i intelektualnej średniowiecza ofiarowane Profesorowi Krzysztofowi Ożogowi, red. W. Świeboda, M. Zdanek, Kraków 2016, s. 282.

${ }^{16}$ W. Wisłocki, Katalog rekopisów Biblijoteki Uniwersytetu Jagiellońskiego, Kraków 18771881, cz. 1, s. 133.

${ }^{17}$ Acta rectoralia Almae Universitatis studii Cracoviensis inde ab anno MCCCCLXIX, ed. W. Wisłocki, Cracoviae 1894, nr 626, s. 133.

${ }^{18}$ BJ, rkps 248, k. 127r. Zob. Catalogus codicum manuscriptorum medii aevi Latinorum qui in Bibliotheca Jagellonica Cracoviae asservantur, t. 1, oprac. S. Włodek, G. Zathey, M. Zwiercan, Wratislaviae-Varsaviae-Cracoviae-Gedani 1980, s. 280-286 (M. Kowalczyk, Opis cod. 248). Anna Lewicka-Kamińska błędnie zinterpretowała zapiskę w rękopisie BJ 248, k. 127r (in celario testudinato sub libraria) jako dowód na to, że biblioteka mieściła się na piętrze. Zob. Lewicka-Kamińska, Biblioteka Jagiellońska, s. 260. Tymczasem mowa tu o zadaszonej piwnicy pod salą biblioteczną, co wskazuje, że biblioteka mieściła się na parterze.

${ }^{19}$ Włodarek, Architektura średniowiecznych kolegiów, s. 31-32, 199.

${ }^{20}$ Świeboda, Na tropie średniowiecznych rękopisów, s. 288.

${ }^{21}$ L. Hajdukiewicz, Księgozbiór i zainteresowania bibliofilskie Piotra Tomickiego na tle jego działalności kulturalnej, Wrocław 1961 („Monografie z Dziejów Nauki i Techniki”, t. 18), s. 130; H. Barycz, Historia Uniwersytetu Jagiellońskiego w epoce Humanizmu, Kraków 1935, s. 728-729.

${ }^{22}$ A. Sobańska, List o pożarze Krakowa w roku 1455 z rękopisu Mikołaja Byliny, „Studia Mediewistyczne", 31 (1994) s. 127; Włodarek, Architektura średniowiecznych kolegiów, s. 194.

${ }^{23}$ Świeboda, Na tropie średniowiecznych rękopisów, s. 285.

${ }^{24}$ Włodarek, Architektura średniowiecznych kolegiów, s. 214. 
się porządkowaniem biblioteki uniwersyteckiej oszacował liczbę rękopisów biblioteki jurystów na 50 obiektów ${ }^{25}$. Kwerenda, którą przeprowadziłem przed paru laty w zbiorach Biblioteki Jagiellońskiej, potwierdziła zachowanie przynajmniej 53 rękopisów, w tym 46 średniowiecznych ${ }^{26}$. Z kolei pośród książek wydanych do końca XVI wieku, których przynależność do biblioteki Collegium Iuridicum jest poświadczona adnotacją proweniencyjną, znane są trzy inkunabuły stanowiące niegdyś jeden klocek $^{27}$ i 35 druków ${ }^{28}$.

Nie zachowały się żadne statuty określające sposób wyboru opiekunów księgozbioru Kolegium Prawniczego lub mówiące o powierzonych im zadaniach czy obowiązkach. Możemy się jedynie domyślać, że kompetencje bibliotekarza były podobne jak w Collegium Maius, o czym była wyżej mowa. Uzyskanie dodatkowych informacji jest możliwe dzięki przebadaniu śladów działalności bibliotecznej Jana ze Skawiny, postaci szczególnie oddanej swojej pracy kustosza.

\section{Jan ze Skawiny}

Jan ze Skawiny, zwany też Skawinką (†1520), z pewnością nie był postacią pierwszoplanową, jeśli chodzi o grono profesorskie, a jego życiorys na tle innych uczonych krakowskich przedstawia się stosunkowo skromnie. Jedyny jego biogram został opracowany przez Dagmarę Wójcik-Zegę w albumie prezentującym sylwetki profesorów Wydziału Prawa wykładających w Krakowie ${ }^{29}$. Fakty z życia uczonego przedstawione $\mathrm{w}$ niniejszej publikacji powtarzają ustalenia autorki, jedynie nieznacznie je uzupełniając lub korygując. Jan ze Skawiny na Uniwersytet Krakowski wpisał się w semestrze letnim 1462 roku $^{30}$. Trzy lata później zdobył bakalaureat ${ }^{31}$, a magisterium na początku $1469 \mathrm{roku}^{32}$. Na studia wyższe wyjechał do Rzymu, gdzie w 1475 roku otrzymał stopień doktora dekretów na Wydziale Prawa na Uniwersytecie Kurialnym ${ }^{33}$. W 1479 roku ponownie wzmiankowany

${ }^{25}$ J.S. Bandtkie, Historya Biblioteki Uniwersytetu Jagiellońskiego w Krakowie, Kraków 1821, s. 10 .

${ }^{26}$ Dokładnie odnalazłem 43 rękopisy posiadające notę proweniencyjną jednoznacznie wskazującą na Collegium Iuridicum oraz 10 kolejnych posiadających wpisy Jana ze Skawiny, co może wskazywać na przynależność obiektów do tejże biblioteki. Świeboda, Na tropie średniowiecznych rękopisów, s. 292-304.

${ }^{27}$ Inkunabuly Biblioteki Jagiellońskiej, oprac. A. Lewicka-Kamińska, Kraków 1962, s. 241. Decyzję o rozdzieleniu klocka na 3 osobne druki podjęto w czasie prac konserwatorskich w 1936 roku. Zob. adnotację Ludwika Birkenmajera na wyklejkach górnych okładek Inc. 3022, 3023 i 3024.

${ }^{28}$ Katalog poloników XVI wieku Biblioteki Jagiellońskiej, t. 3: Indeksy, red. M. Malicki, E. Zwinogrodzka, oprac. M. Gołuszka i in., Kraków 1995, s. 248.

${ }^{29}$ D. Wójcik-Zega, Jan ze Skawiny, w: Profesorowie Wydziatu Prawa Uniwersytetu Jagiellońskiego, t. 1: 1364-1780, red. W. Uruszczak, Kraków 2015, s. 146.

${ }^{30}$ Metryka Uniwersytetu Krakowskiego z lat 1400-1508, wyd. A. Gąsiorowski, T. Jurek, I. Skierska, przy współpr. R. Grzesika, t. 1, Kraków 2004, s. 295 [62e/17].

${ }^{31}$ Najstarsza ksiega promocji Wydziału Sztuk Uniwersytetu Krakowskiego z lat 1402-1541, wyd. A. Gąsiorowski, T. Jurek, I. Skierska, Warszawa 2011, s. 229 [65/52B].

32 Tamże, s. 232 [69/9M].

${ }^{33}$ H. Barycz, Polacy na studiach w Rzymie w epoce Odrodzenia (1440-1600), Kraków 1938, s. 43. 
jest wśród członków uczelni krakowskiej, gdzie rozpoczął wykłady na Wydziale Prawa. W 1489 roku został przyjęty do społeczności Collegium Iuridicum. W latach 1508-1511 mieszkał w Domu Kanonicznym ${ }^{34}$, po czym powrócił do gmachu uniwersyteckiego na ulicy Grodzkiej, stając się przełożonym domu (praepositus domus) $)^{35}$. W latach 1482-1485 był prokuratorem Uniwersytetu do spraw majątkowych, w 1485 roku został wybrany do grona profesorów zatwierdzających statuty Bursy Długosza, w której zamieszkiwali studenci prawa, trzy lata później zaś występował jako jeden z ekspertów mających zadanie ułożenia nowych statutów Bursy Jerozolimskiej. W semestrze letnim 1495 roku oraz zimowym 1497/1498 pełnił rolę konsyliarza przy boku rektora. W 1507 roku był prowizorem Bursy Ubogich. Dziekanem Wydziału Prawa był co najmniej pięciokrotnie: prawdopodobnie w semestrze zimowym 1490/1491, letnim 1507, zimowym 1510/1511, zimowym 1513/1514, letnim 1515, a także wicedziekanem w semestrze letnim 1512 roku $^{36}$. W czasie swojej kadencji dziekańskiej w 1507 roku nadzorował prace remontowe gmachu na ul. Grodzkiej oraz przyczynił się do doprowadzenia kanalizacji do budynku ${ }^{37}$.

Jego kariera jako duchownego zaczęła się rozwijać stosunkowo późno. Nie wiadomo, kiedy przyjął święcenia kapłańskie. Jako kleryk został wymieniony w 1476 roku $^{38}$, do 1519 roku pełnił posługę altarysty ołtarza św. Łazarza w kościele pw. św. Marii Magdaleny w Krakowie, a w latach 1495-1507 dodatkowo ołtarza św. Tomasza z Akwinu na Wawelu. Jako pleban w rodzinnej Skawinie wymieniany jest w źródłach w latach 1501-1505. W 1516 roku wspomógł fundację ołtarza Nawiedzenia NMP w tymże kościele. Od 1512 roku aż do swojej śmierci w związku z prowadzeniem wykładów na Wydziale Prawa otrzymywał uposażenie plebańskie z kościoła parafialnego w Luborzycy. Być może już w 1489 roku ${ }^{39}$, a na pewno w 1492 roku został kanonikiem skarbimierskim (obecnie: Skalbmierz). W 1495 roku został upoważniony przez cesarza Fryderyka III do ustanawiania notariuszy z mianowania cesarskiego (jako tzw. vicecomes). W testamencie zapisał swój majątek na rzecz klasztoru Paulinów na Skałce na Kazimierzu ${ }^{40}$.

${ }^{34}$ Wójcik-Zega, Jan ze Skawiny, s. 146.

${ }^{35}$ BJ, rkps 248, k. 1v. Zob. Catalogus, t. 1, s. 285-286 (Kowalczyk, Opis cod. 248).

${ }^{36}$ BJ, rkps 248, k. 3r, 69r, 139r; Wójcik-Zega, Jan ze Skawiny, s. 146-147.

${ }^{37} \mathrm{BJ}$, rkps $248, \mathrm{k} .10 \mathrm{v}-11 \mathrm{r}$.

${ }^{38}$ J. Kurtyka, Leńcze, w: Stownik historyczno-geograficzny województwa krakowskiego w średniowieczu, cz. 3, red. F. Sikora, Kraków 2000, s. 537.

${ }^{39} \mathrm{~W}$ tym bowiem roku został kolegiatem Wydziału Prawa, a więc prawdopodobnie otrzymał beneficium pozwalające mu na utrzymanie się z prowadzenia wykładów. Zapiska Jakuba z Szadka w Metryce Uniwersyteckiej również wskazywałaby na posiadanie przez Jana ze Skawiny kanonii skarbimierskiej w momencie dołączenia przez niego do grona kolegiatów: „,collegiatus canonistarum 1489 ipso die Ad vincula sancti Petri et canonicus Skarbimiriensis”. Zob. Metryka, t. 1, s. 295.

${ }^{40}$ Wójcik-Zega, Jan ze Skawiny, s. 147; Wypisy źródłowe do dziejów Wawelu 1440-1500, oprac. B. Przybyszewski, Kraków 1960, nr 164, s. 105-106. 
Pośród rękopisów należących do tamtejszego archiwum nie znajdujemy żadnych kodeksów przekazanych przez Jana ${ }^{41}$, co pozwala sądzić, że większość z nich podarował albo członkom swojej rodziny, albo bibliotece jurystów.

Zupełnie nieznana pozostaje dla nas spuścizna pisarska Jana ze Skawiny. Brak zachowania jakichkolwiek dzieł jego autorstwa może być skutkiem wspomnianych pożarów budynku fakultetu prawa. Wszelkie informacje o jego działalności jako bibliotekarza Collegium Iuridicum posiadamy wyłącznie z zapisek zamieszczonych na obiektach wchodzących w skład tamtejszego księgozbioru. Po raz pierwszy na tej funkcji występuje on w $1501 \mathrm{roku}^{42}$, a krańcową datą wpisów jego ręką jest rok $1515^{43}$. Ponadto pojawiają się jeszcze daty 1505,1508 i 1509. Trudno jednoznacznie orzec, czy uczony sprawował opiekę nad biblioteką prawniczą nieprzerwanie przez 15 lat, czy też wymiennie z innymi profesorami wykładającymi wówczas na wydziale. W tamtym czasie na fakultecie prawniczym zajęcia prowadziło siedmiu wykładowców, przy czym byli to zarówno kolegiaci zamieszkujący Collegium Iuridicum, jak i profesorowie dochodzący, a także senior Bursy Prawników. Pierwszy z doktorów wykładał Dekret Gracjana, drugi - tzw. lector ordinarius - objaśniał pierwszą i drugą księgę Dekretałów papieża Grzegorza IX, kolejnych dwóch - pozostałe trzy księgi Dekretałów, a trzech innych profesorów - zbiór praw nowych czyli Księgę Szósta i Klementyny ${ }^{44}$. Jan ze Skawiny najczęściej prowadził zajęcia z lektury tzw. praw nowych, rzadziej Dekretałów (prawdopodobnie w zastępstwie) ${ }^{45}$. Ciekawostką jest fakt, że nawet po wyprowadzce z Collegium Iuridicum kuratela nad księgozbiorem nadal była powierzana jego opiece, jak to było choćby w 1509 roku.

\section{Dzialalność bibliotekarska Jana ze Skawiny}

Trwałym śladem działalności Jana Skawińskiego jako bibliotekarza było uporządkowanie księgozbioru prawników. Wiele z tamtejszych kodeksów posiada jego wpisy świadczące jednoznacznie o przynależności obiektów do biblioteki Collegium Iuridicum. Nie były to jednak żadne sygnatury czy oznaczenia szaf, ale zapiski wskazujące na bibliotekę Wydziału Prawa jako instytucję będącą właścicielem danego obiektu. Niekiedy były one uzupełniane informacją o dotychczasowych posiadaczach, ich funkcjach i stopniach naukowych oraz dacie przekazania kodeksu do biblioteki. Na zachowanych 46 rękopisów, które w 1520 roku znajdowały się w bibliotece Kolegium Prawniczego, aż 39 posiada noty wpisane ręką Jana ze Skawiny (zob. tab. 1).

${ }^{41}$ Zob. Z. Kowalska-Urbankowa, J. Zbudniewek ZP, Katalog rękopisów biblioteki paulinów w Krakowie na Skatce, „Studia Claromontana”, 8 (1987) s. 269-500.

${ }^{42}$ BJ, rkps 404, k. 1r. Zob. Catalogus, t. 2, oprac. M. Kowalczyk i in., Wratislaviae-VarsaviaeCracoviae-Gedani-Lodziae 1982, s. 200 (Zwiercan, Opis cod. 404).

${ }^{43}$ BJ, rkps 2508, k. 1r; rkps 2513, k. Ir; rkps 2516, k. 1r. Zob. Wisłocki, Katalog rękopisów, cz. 2, s. 598-600.

${ }^{44}$ Barycz, Historia Uniwersytetu Jagiellońskiego, s. 191; Sroka, Studia prawnicze, s. 13. W swoim artykule (Na tropie średniowiecznych rękopisów, s. 284, przypis 25) mylnie podałem wykaz katedr, który funkcjonował na początku XV wieku, a nie w XVI wieku.

${ }^{45}$ BJ, rkps 248, k. 7v; Wójcik-Zega, Jan ze Skawiny, s. 146-147. 
Tabela 1. Wpisy Jana ze Skawiny w rękopisach biblioteki Wydziału Prawa

\begin{tabular}{|c|c|}
\hline Sygnatura & Nota proweniencyjna wpisana ręką Jana ze Skawiny \\
\hline 143 & $\begin{array}{l}\text { K. IIr: liber magistri Johannis de Skavina decretorum doctoris } 1488 \text { legatus per } \\
\text { dominum Petrum; legatus pro [skreślone: notariis consistorii Cracoviensis] 1505; } \\
\text { pro Stanislao de Myslynycze }\end{array}$ \\
\hline 293 & K. 1r: pro Collegio Canonistarum legatus \\
\hline 327 & K. 3r: Tituli legum cum vocabulo iuris pro Collegio Canonistarum \\
\hline 333 & K. IIIv: pro Collegio Canonistarum \\
\hline 342 & $\begin{array}{l}\text { F. 1r: [ręką Jakuba z Zaborowa:] Iste liber est magistri Jacobi de Zaborow canonici } \\
\text { Cracoviensis, decretorum doctoris [dopisek Jana ze Skawiny:] et decreti lectoris in } \\
\text { studio Cracoviensi et altariste s. Lazary in capella sancte Marie Magdalene }\end{array}$ \\
\hline 344 & K. Ir: pro Collegio Iuristarum \\
\hline 345 & $\begin{array}{l}\text { K. IIr: [ręką Arnolfa z Mierzeńca:] Liber Arnolphi de Myrzynyecz, baccalaureum } \\
\text { arcium et in decretis [ręką Jana ze Skawiny:] Casus in terminis super quinque libros } \\
\text { Decretalium pro domo et Collegio Canonistarum datus }\end{array}$ \\
\hline 367 & $\begin{array}{l}\text { K. IIr: Iste liber est Lectura tercii Decretalium maystri [!] Iohannis de Skavina de- } \\
\text { cretorum doctoris in curia Romana promoti } 1475 \text { in vigilia sancti Andree Apostoli, } \\
\text { pro domo et libraria Collegii Canonistarum lego, manu propria signavit } 1505\end{array}$ \\
\hline 368 & $\begin{array}{l}\text { K. IIv: Lectura super secundum librum Decretalium maystri [!] Iohannis de Skaw- } \\
\text { ina, decretorum doctoris 1476, pro domo Canonistarum legatus per eundem, manu } \\
\text { propria signavit } 1505\end{array}$ \\
\hline 378 & $\begin{array}{l}\text { 1) na wyklejce górnej oprawy: Lectura super quartum librum Decretalium pro do- } \\
\text { mus Collegii dominorum Canonistarum; } \\
\text { 2) k. 1r [inną ręka]: Lectura quarti legata per dominum Petrum Scolteti de Crosna, } \\
\text { decretorum doctoris, [dopisek Jana ze Skawiny:] pro domo dominorum Canonista- } \\
\text { rum }\end{array}$ \\
\hline 403 & K. 1r: pro domo Canonistarum Repeticiones Calderini in iure canonico \\
\hline 404 & $\begin{array}{l}\text { K. 1r: Liber magistri Iohannis de Skavina decretorum doctoris et in Skavina plebani, } \\
\text { in Curia promoti } 1475 \text { in vigilia sancti Andree Apostoli, legatus pro Collegio Can- } \\
\text { onistarum millesimo quingentesimo primo }\end{array}$ \\
\hline 407 & $\begin{array}{l}\text { K. Ir: } 1509 \text { pro domo Canonistarum et libraria eiusdem in Cracovia doctor Skavin- } \\
\text { sky librarista scripsit }\end{array}$ \\
\hline 1214 & K. IIr: pro domo et libraria domus Collegii legatus \\
\hline 1229 & $\begin{array}{l}\text { K. IIr: Augustini de Anchona, fratrum Heremitarum ordinis sancti Augustini, pro } \\
\text { domo Canonistarum }\end{array}$ \\
\hline 1242 & $\begin{array}{l}\text { K. IIr: Distincciones exemplorum Veteris et Novi Testamenti, et tractatus sancti } \\
\text { Bernhardi, et in fine tractatus VII sigillorum Domini, pro Collegio domus Canoni- } \\
\text { starum legatus }\end{array}$ \\
\hline 124 & $\begin{array}{l}\text { Nalepka na k. IIr: Scriptum Boneventure [!] super primum librum Sententiarum doc- } \\
\text { toris Arnolphi pro domo et libraria Canonistarum }\end{array}$ \\
\hline
\end{tabular}




\begin{tabular}{|c|c|}
\hline 1295 & K. IIr: Repertorium Gvylhelmi Durandi pro Collegio Canonistarum Cracovie \\
\hline 1301 & $\begin{array}{l}\text { K. 1v [inną ręką]: Excerpta de Bertrando super epistolas dominicales et quadra- } \\
\text { gesimales [dopisek Jana ze Skawiny:] pro collegio Canonistarum }\end{array}$ \\
\hline 1344 & K. IIIr: pro domo Canonistarum legatus \\
\hline 1410 & $\begin{array}{l}\text { K. Ir : Item postea legatus magistro Iohanni de Skawina decretorum doctori et in } \\
\text { Skawina plebano, qui eundem librum legavit [skreślone: pro canonico et collegia- } \\
\text { to protunc domus Canonistarum in Cracovia 1505] pro Stanislao presbitero de } \\
\text { Myszlymycze, sororio meo. Hic in principio continentur Scala celi per ordinem al- } \\
\text { phabeticum. Item concordantie Veteris Testamenti cum Nowo [!], et iuris canonici. } \\
\text { Item Hystoria Romanorum. Item tractatus de penitencia }\end{array}$ \\
\hline 1442 & $\begin{array}{l}\text { K. 1r: Liber quatuor librorum Sentenciarum cum textu doctoris de Saspow, canonici } \\
\text { sancti Floriani, pro domo Collegii Canonistarum }\end{array}$ \\
\hline 1595 & K. Ir: pro domo dominorum Canonistarum Cracovie legatus \\
\hline 1603 & $\begin{array}{l}\text { Wyklejka górnej oprawy: scriptum super quartum Sententiarum magistri Petri Lom- } \\
\text { bardi }\end{array}$ \\
\hline 1629 & $\begin{array}{l}\text { K. IIr: Sermones super Proverbia Salomonis et incipit “O, sapiencia”, pro Collegio } \\
\text { canonistarum }\end{array}$ \\
\hline 2389 & K. Ir: 1508 doctor Bartholomeus de Zneyna pro domo Canonistarum legavit \\
\hline 2392 & $\begin{array}{l}\text { K. Ir: Diverse compilaciones dominicanarum }[. . .] \text { peregrinatio ad Terram Sanctam } \\
\text { et deinde alia plura, doctoris Arnolphi pro domo Canonistarum legatus ipsiusque } \\
\text { libraria }\end{array}$ \\
\hline 2398 & $\begin{array}{l}\text { K. Ir: In principio huius sunt XV libri sancti Augustini de Trinitate, deinde varii } \\
\text { tractatus, pro Collegio Canonistar }<u m>\end{array}$ \\
\hline 2399 & $\begin{array}{l}\text { 1) k. 1r: doctoris Skavinam } \\
\text { 2) k. 151v [ręką Piotra ze Skawiny]: Liber domini Petri Skawynsky et fuit olim do- } \\
\text { mini Mathie de Ruszcza, oretur pro eo Deus et Virgo, mater eius; [dopisek Jana ze } \\
\text { Skawiny:] et post magistri Iohannis Skawynsky, decretorum doctoris, per dominum } \\
\text { Petrum, filiastrem suum, sibi legatus } 1488 \text { ipso die sancti Vincencii confessoris }\end{array}$ \\
\hline 2400 & $\begin{array}{l}\text { K. } 2 \mathrm{v}-3 \mathrm{r} \text { : magistri Johannis de Pysdri decretorum doctoris, altariste maioris ec- } \\
\text { clesie, predicatoris Polonorum ad s. Barbaram in doctoris promoto anno } 1481 \text {. } \\
\text { Coczwara }\end{array}$ \\
\hline 2401 & $\begin{array}{l}\text { K. 1r [inną ręką]: Tractatus de horis canonicis dicendis, [dopisek Jana ze Skawiny:] } \\
\text { pro domo Canonistarum doctoris Arnolphi legatus }\end{array}$ \\
\hline 2402 & $\begin{array}{l}\text { Na wyklejce górnej oprawy: doctor Bartholomeus plebanus ad s. Annam legavit pro } \\
\text { domo canonistarum anno } 1508\end{array}$ \\
\hline 2415 & $\begin{array}{l}\text { K. Ir: [ręka Piotra ze Skawiny]: Iste liber est domini Petri Skawynsky altariste ecc- } \\
\text { lesie s. Marie emptus per eundem apud dominum Iacobum Grzemyelensky pro } 2 \\
\text { florenis [dopisek Jana ze Skawiny:] et legatus magistro Johanni de Skavina decre- } \\
\text { torum doctori }\end{array}$ \\
\hline 2416 & $\begin{array}{l}\text { Na wyklejce górnej oprawy: Sermones de tempore et de passionis Christi, doctoris } \\
\text { Arnolphi pro libraria domus Canonistarum }\end{array}$ \\
\hline 2508 & K. 1r: 1515 doctoris Skavina Sermones legatis [!] Stanislao presbitero de Myslynycze \\
\hline
\end{tabular}




\begin{tabular}{|l|l|}
\hline 2513 & K. Ir: pro Collegio Iuristarum magistri Johannis doctor Skawina 1515 \\
\hline 2515 & K. Ir: Summa confessorum fratris Iohannis predicatorum, pro Collegio Iuristarum \\
\hline 2516 & $\begin{array}{l}\text { K. 1r: Liber doctoris Skawina olim domini Petri legatus pro [skreślone: magistro } \\
\text { Stanislao licenciato in theologia, preposito s. Hedvigis in Ponte Regali 1505]; pro } \\
\text { Stanislao presbitero de Myslynicze detur 1515 III Iulii. }\end{array}$ \\
\hline 2537 & K. Iv: pro Collegio domus canonistarum \\
\hline
\end{tabular}

Źródło: badania własne.

Część z wymienionych kodeksów stanowiła pierwotnie własność uczonego (rkps 143, 367, 368, 404, 407, 1410, 2399, 2415, 2508, 2513, 2516, 3257), inne zostały przekazane do zasobów jako dary różnych profesorów. W kilku przypadkach sposób pozyskania ich przez bibliotekę nie jest jasny. Spośród pozostałych zachowanych rękopisów z księgozbioru Wydziału Prawa w okresie sprawowania funkcji bibliotekarza przez Jana ze Skawiny dwa posiadają średniowieczne wpisy dokonane przez innych kustoszy bibliotecznych (rkps 471, 1184), wpisy dwóch kolejnych zostały sporządzone w XVIII wieku (rkps 1609, 1624), dwa inne zaś wprawdzie obecnie nie posiadają not proweniencyjnych (rkps 1291, 1742), ale widniały one na oprawach, które nie przetrwały do naszych czasów ${ }^{46}$. Tylko w jednym przypadku (rkps 3257) imię Jana ze Skawiny jako ofiarodawcy zostało wymienione w adnotacji sporządzonej inną ręką z XVI wieku na górnym obcięciu kart (zob. tab. 2) $)^{47}$.

Tabela 2. Rękopisy biblioteki Wydziału Prawa z wpisami innych bibliotekarzy

\begin{tabular}{|l|l|}
\hline Sygnatura & \multicolumn{1}{c|}{ Nota proweniencyjna } \\
\hline 471 & K. IIr: Pro libraria canonistarum legatus \\
\hline 1184 & Trudno czytelny palimpsest na k. 104v: Pro Collegio Canonistarum [?] \\
\hline 1291 & $\begin{array}{l}\text { Na niezachowanej oprawie: }<\text { Domini Arnolphi Myrszyniecz pro domo canonista- } \\
\text { rum> }\end{array}$ \\
\hline 1609 & K. 1r: Bibliothecae Collegium Iuridicum \\
\hline 1624 & K. 1r: Bibliothecae Collegium Iuridicum \\
\hline 1742 & $\begin{array}{l}\text { Na niezachowanej oprawie: }<\text { Liber Arnolphi doctoris, Iliber Summe fratris Thome } \\
\text { de Aquino, de ordine Predicatorum, pro domo Collegii canonistarum datus }>\end{array}$ \\
\hline 3257 & $\begin{array}{l}\text { Na górnym obcięciu kart: Scriptura Decretales ex donacione domini Ioannis de } \\
\text { Skavina }\end{array}$ \\
\hline
\end{tabular}

Źródło: Badania własne.

${ }^{46}$ Zapiski na oprawach były jeszcze znane Jerzemu Samuelowi Bandtkiemu na początku XIX wieku. Wisłocki, Katalog rękopisów, cz. 1, s. 325, 419.

${ }^{47}$ Zob. Świeboda, Na tropie średniowiecznych rękopisów, s. 302. W artykule błędnie zidentyfikowałem pismo jako autograf Jana ze Skawiny. 
Zapiski własnościowe Jana ze Skawiny najczęściej były zamieszczane na przednich kartach ochronnych lub pierwszych kartach rękopisu, rzadziej na innych kartach czy wyklejkach, a tylko w pojedynczych przypadkach na oprawie. Nierzadko informacja proweniencyjna była dopisywana przez doktora prawa do już istniejących notatek własnościowych, tworząc niejako dalszy ich ciąg. W przypadku niektórych kodeksów noty przez niego zostawione są jedynymi wskazówkami pozwalającymi określić właścicieli lub ustalić jakiekolwiek fakty związane z historią rękopisu. Wpisy dokonywane przez uczonego świadczą o jego rzetelności w rejestrowaniu obiektów rękopiśmiennych należących do księgozbioru biblioteki prawniczej. Podobnie czynili niektórzy bibliotekarze pozostałych bibliotek Uniwersytetu Krakowskiego, czego dowodzą zachowane noty proweniencyjne w rękopisach Biblioteki Jagiellońskiej.

W chwili objęcia funkcji kustosza przez Jana ze Skawiny w bibliotece prawniczej znajdowała się spuścizna rękopiśmienna Arnolfa z Mierzeńca († przed 4 stycznia 1491 roku), doktora prawa kanonicznego i teologii, wieloletniego profesora Collegium Iuridicum, rektora Uniwersytetu Krakowskiego, dziekana Wydziału Prawa jak i Teologicznego ${ }^{48}$. Pokaźny księgozbiór został podzielony przez samego uczonego na dwie części. Pierwsza z nich trafiła do bibliotek różnych wydziałów uniwersytetu, być może u schyłku życia profesora lub po jego śmierci, druga do kapituły katedralnej krakowskiej między 1480 a 1490 rokiem $^{49}$. Z biblioteki Kolegium Jurystów zachowało się aż 11 kodeksów pochodzących z jego donacji (rkps 345, 1214, 1229, prawdopodobnie 1242, 1246, 1291, 1742, 2392, 2401, 2416, 2537). Wśród dzieł typowo prawniczych, które się w nich znajdują, należy wymienić Casus longi super quinque libris Decretalium autorstwa Bernarda de Bottone (rkps 345), Lectura super epistulas canonicas Augustyna z Ankony (rkps 1229) oraz dekrety soboru bazylejskiego wraz z pomniejszymi kwestiami różnych autorów (rkps 2392). Pozostałe zawierają teksty o charakterze typowo teologicznym lub kaznodziejskim, w tym dzieło Liber conclusionum Evangelicae veritatis Stanisława ze Skarbimierza (rkps 2416$)^{50}$ oraz traktaty innych uczonych krakowskich: Mateusza z Krakowa Dialogus conscientiae et rationis (rkps 1291), Benedykta Hesse z Krakowa o lichwie (rkps 2392) i Jakuba z Paradyża De malis huius saeculis (rkps 2401) ${ }^{51}$. Niektóre wpisy Jana ze Skawiny jednoznacznie wymieniają imię Arnolfa z Mierzeńca jako ostatniego właściciela i donatora obiektów, inne jedynie wskazują miejsce docelowe przekazu. Dwa kodeksy z jego biblioteki nie otrzymały oznaczeń, a jeśli takie były, to nie dotrwały do naszych czasów (por. tab. 1).

Formuły proweniencyjne zostały zamieszczone przez Jana ze Skawiny także w kodeksach bibliotecznych należących uprzednio do innych doktorów prawa. Być może były to dary pochodzące bezpośrednio od wymienionych osób bądź od kolejnych właścicieli lub spadkobierców, których imion nie znamy. Znajduje-

\footnotetext{
${ }^{48}$ M. Zdanek, Arnolf z Mierzeńca, w: Profesorowie Wydziału Prawa, t. 1, s. 18-19.

${ }^{49}$ Szelińska, Biblioteki profesorów, s. 114-122.

${ }^{50}$ R. Zawadzki, Spuścizna pisarska Stanisława ze Skarbimierza. Studium źródłoznawcze, Kraków 1979, s. 40-41, 65-69.

${ }^{51}$ Świeboda, Na tropie średniowiecznych rękopisów, s. 310-316.
} 
my zatem po jednym kodeksie: Piotra Wolframa $(\uparrow 1428)$ - przywieziony z Włoch $z$ różnymi traktatami teologicznymi i prawniczymi (rkps 344) $)^{52}$, Piotra z Krosna $(\dagger$ przed 1440) - z komentarzem Bogusława z Karniowa do czwartej księgi Dekretatów (rkps 378) $)^{53}$, Marcina z Holeszowa $(† 1440)$ - z kolekcją kazań de tempore et de sanctis (rkps 1301) ${ }^{54}$ Jakuba z Zaborowa (†1449) - zawierający XIV-wieczny egzemplarz Księgi Szóstej papieża Bonifacego VIII (rkps 342) ${ }^{55}$ oraz dwa kodeksy Tomasza Strzępińskiego $(† 1460)$ - pierwszy składający się z dzieł prawniczych takich autorów jak m.in. Wilhelm Durand czy Jan z Lignano (rkps 1295) ${ }^{56}$, drugi z decyzjami Roty Rzymskiej (rkps 407) ${ }^{57}$. Jeżeli darczyńcami faktycznie byli wymienieni uczeni, co w przypadku niektórych osób jest mocno wątpliwe, oznaczałoby to wówczas, że obiekty te szczęśliwie przetrwały pożar biblioteki z 1455 roku. Taką pewność możemy mieć jedynie w przypadku ostatniego z wymienionych rękopisów, o ile prawdziwa jest informacja zamieszczona przez Jerzego Samuela Bandtkiego z początku XIX wieku o nocie na kartce przylepionej do oprawy: „Liber Thome Strzempinsky 1446 pro Libraria Collegii Iuristarum in Cracovia"58. Niewykluczone, że z tego samego roku był także legat pierwszego z wymienionych kodeksów należących do uczonego, a zarazem przyszłego biskupa krakowskiego.

Nie wcześniej niż w drugiej połowie XV wieku, a na pewno już po pożarze, w bibliotece znalazł się rękopis będący własnością Macieja z Sąspowa (†1472) zawierający jego komentarz do Sentencji Piotra Lombarda (rkps 1442) ${ }^{59}$. Podobnie mogło być ze zbiorem mów rekomendacyjnych i okolicznościowych wygłoszonych na Uniwersytecie Krakowskim przez Stanisława ze Skarbimierza i Jana Elgota (rkps 2400), będącym w posiadaniu Jana z Pyzdr zw. Koczwara, doktora dekretów ${ }^{60}$. Najwcześniej w 1477 roku został przekazany inny obiekt rękopiśmienny należący do bakałarza dekretów Macieja z Obiecanowa z licznymi dziełami różnorodnej treści, w tym św. Augustyna i statutami prowincjonalnymi gnieźnieńskimi z 1420 roku (rkps 2398) ${ }^{61}$. Możliwe, że kodeks ten znalazł się W spuściźnie Arnolfa z Mierzeńca podobnie jak inny rękopis (syg. 2392) należący uprzednio do Macieja z Obiecanowa. Na kartach wymienionych tu rękopisów Jan ze Skawiny osobiście zanotował jedynie imiona Jana z Pyzdr i Macieja z Sąspowa

${ }^{52}$ Catalogus, t. 2, s. 28-34 (Zwiercan, Opis cod. 344); I. Malinowska-Kwiatkowska, I manoscritti giuridici Bolognesi al Collegium Iuridicum dell' Università Jagellonica (il lascito di Piotr Wolfram), w: Laudatio Bononiae. Atti del Convegno storico italo-polacco svoltosi a Bologna dal 26 al 31 maggio 1988 in occasione del Nono Centenario dell' 'Alma Mater Studiosorum', red. R.C. Lewanski, Varsavia 1990, s. 162; Świeboda, Na tropie średniowiecznych rękopisów, s. 299.

${ }^{53}$ Catalogus, t. 2, s. 136-138 (Zwiercan, Opis cod. 378).

${ }^{54}$ Tamże, t. 8, oprac. M. Kowalczyk i in., Cracoviae 2004, s. 184-195 (L. Nowak, Z. Włodek, Opis cod. 1301).

${ }^{55}$ Tamże, t. 2, s. 25-27 (Zwiercan, Opis cod. 342).

${ }^{56}$ Tamże, t. 8, s. 133-137 (K. Bielawska, M. Kowalczyk, Opis cod. 1295).

${ }^{57}$ Tamże, t. 2, s. 205-208 (M. Kowalczyk, J. Zathey, Opis cod. 407).

${ }^{58}$ Wisłocki, Katalog rękopisów, cz. 1, s. 133.

${ }^{59}$ Catalogus, t. 10, oprac. A. Kozłowskai in., Cracoviae 2012, s. 49-51 (Z. Włodek, K. Wójcik, L. Nowak, Opis cod. 1442).

${ }^{60}$ BJ, rkps 2400, k. 2v-3r. Zob. Wisłocki, Katalog rękopisów, cz. 2, s. 575.

${ }^{61}$ Metryka, t. 1, s. 340 [70e/107]; Wisłocki, Katalog rękopisów, cz. 2, s. 574-575. 
jako darczyńców, z kolei do własnoręcznej zapiski własnościowej Jakuba z Zaborowa dopisał pełnione przez niego funkcje, natomiast przy informacji o darze Piotra z Krosna dodał: ,pro domo dominorum Canonistarum” (zob. tab. 1).

Warto też wspomnieć o dwóch księgach rękopiśmiennych, które zostały opatrzone stosownym wpisem o przynależności bibliotecznej przez bibliotekarzy pełniących tę funkcję przed Janem ze Skawiny. Pierwszy z nich (rkps 1184) został zakupiony przez doktora teologii Mikołaja Kozłowskiego $(\dagger 1443)^{62}$, drugi (rkps 471) należał do doktora prawa Mikołaja Spicymira z Krakowa $(\dagger 1468)^{63}$.

W bibliotece Wydziału Prawa na początku XVI wieku znajdowały się także rękopisy o nierozpoznanej proweniencji lub pochodzące od bliżej nieznanych osób. Tak jest np. z kolekcją różnych kazań przeplecionych fragmentami biblijnymi należącą do niejakiego Zelico z Pragi, a potem pewnego Jakuba, prezbitera w kościele Wszystkich Swiętych w Krakowie (rkps 1344) ${ }^{64}$. Inny manuskrypt został przepisany przez Mikołaja ze Świdnicy (nie wiadomo, o którego dokładnie chodzi), a zawiera konkordancje biblijne oraz traktat Jana z Nivelle Allegationes Veteris et Novi Testamenti (rkps 1595) ${ }^{65}$. Zupełnie nic nie da się natomiast powiedzieć o właścicielach kodeksów: 293, 327, 333, 403, 1603, 1609, 1624, 1629 i 2515. Dwa przedostatnie (rkps 1609 i 1624) mogły zostać włączone do biblioteki Wydziału Prawa nawet po okresie działalności bibliotekarskiej Jana ze Skawiny, ponieważ noty o przynależności do Collegium Iuridicum zostały naniesione dopiero w XVIII wieku (zob. tab. 2).

Jan Skawiński w 1508 roku osobiście przyjął dar książkowy od doktora prawa Bartłomieja ze Żnina. Profesor ten już wcześniej zapisał się w pamięci kolegiatów jako fundator uposażenia dla wykładowców na Wydziale Prawa w 1505 roku w wysokości 12 grzywien rocznie dla altarysty ołtarza św. Anny w kościele pod wezwaniem tej świętej. Jako ustępujący dziekan Wydziału Prawa na krótko przed swoją śmiercią ofiarował na rzecz biblioteki Collegium Iuridicum dwa rękopisy o tematyce prawniczej (rkps 2389 i 2402). Drugi z podarowanych kodeksów (rkps 2402) należał wcześniej do doktora teologii Mikołaja ze Stawu (†1490), który postanowił zapisać go bibliotece Wydziału Prawa ${ }^{66}$. Bartłomiej ze Żnina został wyznaczony na egzekutora testamentu, przy czym, jak widać po datach, ostatnią wolę swojego przyjaciela wypełnił dopiero 18 lat po jego śmierci. Niewykluczone, że uzyskał on zgodę swojego mocodawcy na dożywotnie korzystanie z dzieł znajdujących się w rękopisie na takiej samej zasadzie, jak miało to miejsce w przypadku kodeksu o sygnaturze 3248, który profesor Maciej z Kobylina zapisał w testamencie bibliotece Wydziału Teologicznego, ale z klauzulą, że przekazanie

${ }^{62}$ Catalogus, t. 6, s. 425-427 (M. Markowski, Z. Włodek, Opis cod. 1184).

${ }^{63}$ Tamże, t. 2, s. 61-64 (Kowalczyk, Opis cod. 471).

${ }^{64}$ Tamże, t. 8, s. 325-345 (G. Wodzinowska-Taklińska, R. Tatarzyński, Opis cod. 1344).

${ }^{65}$ Wisłocki, Katalog rękopisów, cz. 1, s. 386.

${ }^{66}$ Nota na wyklejce górnej rękopisu BJ 2402: „Iste liber est datus pro domo dominorum canonistarum per venerabilem ac egregium virum magistrum Nicolaum de Staw, professorem sacre theologie, canonicum sancti Floriani, qui finem vite sue clausit feria secunda in festo Felicis et Aucti anno Domini M CCCC 90. Oretur pro eo". Zob. Wisłocki, Katalog rękopisów, cz. 2, s. 577. 
ma mieć miejsce dopiero po śmierci Bartłomieja ze Żnina ${ }^{67}$. Wypada nadmienić, że kilka innych ksiąg zawierających teksty o tematyce teologicznej, filozoficznej i medycznej Bartłomiej ze Żnina przekazał na rzecz pozostałych dwóch bibliotek uniwersyteckich ${ }^{68}$.

Jan ze Skawiny zadbał również o powiększenie zbioru bibliotecznego, przekazując osobiście do biblioteki swój księgozbiór. Darowizny czynił w różnych latach między 1501-1515 rokiem, przy czym nie wszystkie rękopisy trafiły od razu bezpośrednio na półki w Collegium Iuridicum. Część z nich Jan ofiarował swoim krewnym i nie do końca wiadomo, w jaki sposób finalnie znalazły się one w zasobie uniwersyteckim. Warto przyjrzeć się bliżej zawartości poszczególnych kodeksów, gdyż pozwala to na poznanie, przynajmniej częściowe, horyzontów badawczych uczonego, jak również jego zainteresowań naukowych. Na potrzeby zajęć dydaktycznych używał XIV-wiecznego anonimowego komentarza do trzeciej księgi Dekretałów przywiezionego z Pragi przez nieznanego polskiego uczonego (rkps 367). W kodeksie na marginesach znajdują się różne noty i uzupełnienia autorstwa Skawińskiego, co świadczy o tym, iż dzieło to było przez niego komentowane $\mathrm{w}$ ramach działalności naukowej. W rękopisie znajdują się ponadto dwa niewielkie traktaty prawnicze - pierwszy Jana de Deo Breviarium Decretorum, drugi - Jana Andrzejowego Summa de sponsalibus et matrimonio, służące jako komentarz do rozdziału poświęconego małżeństwu z czwartej księgi Dekretałów. Ostatnią część zajmują cztery rekomendacje wygłoszone na Wydziale Prawa Uniwersytetu Praskiego ${ }^{69}$. Do objaśniania z kolei drugiej księgi Dekretałów posługiwał się dwoma komentarzami: pierwszym - anonimowym - pochodzącym z początku XV wieku (rkps 368$)^{70}$, drugim - autorstwa prawdopodobnie Bernarda $z$ Botone $-z$ XIV stulecia (rkps 3257$)^{71}$. Ostatni z wymienionych kodeksów należał niegdyś do Pawła ze Służewa, studenta Uniwersytetu Krakowskiego od $1502 \mathrm{roku}^{72}$, natomiast sposób pozyskania go przez bibliotekę wydziałową pozostaje niejasny. Brakuje w nim bowiem jakichkolwiek wpisów uczonego, co jest sytuacją wyjątkową w kontekście całej jego spuścizny.

Do pomocy przy czynnościach prawnych Jan ze Skawiny posługiwał się zbiorem różnych dzieł prawniczych (rkps 404), spośród których można wymienić: Flores legum autorstwa Juliana z Sesso, De portione canonica Piotra de Ubaldis i Elogium Wilhelma Marcellettiego. Na kartach rękopisu znalazły się także opinia Mikołaja z Wiślicy († 1415/1416), ławnika Sądu Wyższego Prawa Niemieckiego na zamku krakowskim, na temat legalności władzy inkwizytora, opinia Stanisława ze Skarbimierza dotycząca ekskomuniki oraz dwie bulle papieża Bonifacego IX do biskupa Piotra Wysza z 1399 roku. Rękopis należał uprzednio do wspomnianego Mikołaja z Wiślicy, a później innego notariusza Jana Stolle z Głogowa $(\uparrow 1450)$, doktora prawa kanonicznego. Na podstawie pozostawionych not wiado-

\footnotetext{
${ }^{67}$ Szelińska, Biblioteki profesorów, s. 98.

${ }^{68}$ M. Zdanek, Barttomiej ze Żnina, w: Profesorowie Wydziatu Prawa, t. 1, s. 23.

${ }^{69}$ Catalogus, , t. 2, s. 114-117 (Zwiercan, Opis cod. 367).

70 Tamże, t. 2, s. 117-118 (Zwiercan, Opis cod. 368).

${ }^{71}$ Wisłocki, Katalog rękopisów, cz. 2, s. 715-716.

${ }^{72}$ Metryka, t. 1, s. 589 [1502e/143].
} 
mo również, że jego użytkownikiem był doktor dekretów i teologii Maciej z Koła $(† 1441)$. Rękopis o sygnaturze 404 był pierwszym poświadczonym legatem Jana Skawiny na rzecz biblioteki prawników, który miał miejsce w 1501 roku $^{73}$.

Nie posiadamy informacji o tym, w jaki sposób krakowski doktor prawa wszedł w posiadanie rękopisu będącego niegdyś własnością Tomasza Strzępińskiego, a od 1446 roku Wydziału Prawa (rkps 407). Być może po zawirowaniach związanych z pożarem i koniecznością odbudowy gmachu Collegium Iuridicum kodeks znajdował się w rękach prywatnych. Ostatecznie w 1509 roku Jan ze Skawiny ponownie przekazał go do biblioteki ${ }^{74}$. W 1515 roku z kolei ofiarował swój inny rękopis zawierający różne kwestie prawnicze być może autorstwa Marcina z Holeszowa (rkps 2513), który był skrybą, a zarazem pierwszym właścicielem książki. Jedna z przekreślonych not wskazuje na czasową przynależność obiektu do Bursy Ubogich ${ }^{75}$.

W powyższym zestawieniu uwagę zwraca jednorodna tematyka o charakterze ściśle prawniczym. Wśród przekazanych do biblioteki przez Jana ze Skawiny książek znalazły się komentarze do Dekretatów oraz dzieła znanych i cenionych prawników, które z pewnością były używane przez niego w pracy dydaktyczno-naukowej. Z kolei zbiory opinii prawnych (consilia) oraz postanowień sądowych prawdopodobnie służyły mu na co dzień $\mathrm{w}$ jego pracy jako prawnika na Uniwersytecie Krakowskim i wicekomesa do mianowania notariuszy. Ponadto każdy sumienny profesor prawa kanonicznego powinien być zaznajomiony z ustawodawstwem kościelnym oraz znać różne kazusy prawne, stąd obecność tego typu pozycji w księgozbiorze uczonego nie jest zaskoczeniem. Jak zatem widać, dzieła, które Jan Skawiński przekazał na rzecz społeczności Collegium Iuridicum, nie były przypadkowe, a wręcz można powiedzieć, że szczególnie dobrane tematycznie do potrzeb wykładowców i studentów prawa.

Kolejną grupę rękopisów z księgozbioru Wydziału Prawa stanowią obiekty, które w różnym czasie były własnością członków rodziny bibliotekarza. W 1488 roku Jan ze Skawiny otrzymał kilka rękopisów od swojego brata stryjecznego Piotra, altarysty w kościele NMP w Krakowie i kanonika kolegiaty pw. św. Małgorzaty w Nowym Sączu ${ }^{76}$. Pierwszy zawiera dzieło Hugona Ripelina ze Strassburga Compendium theologiae veritatis, przepisane przez Mikołaja z Wieliczki (rkps 2399) ${ }^{77}$. Drugi to zbiór formularzy akt z konsystorza gnieźnieńskiego z lat 1357-1427 (rkps 143), który Piotr otrzymał bezpośrednio od pewnego wikariusza Macieja ze Skawiny. Ze skreślonej zapiski wynika, że początkowo Jan przekazał kodeks lub miał taki zamiar na użytek notariuszy konsystorza krakowskiego, ale w 1505 roku podarował go swojemu siostrzeńcowi Stanisławowi

${ }^{73}$ Catalogus, t. 2, s. 196-200 (M. Zwiercan, Opis cod. 404).

${ }^{74}$ Tamże, t. 2, s. 203-208 (M. Kowalczyk, J. Zathey, Opis cod. 407); Świeboda, Na tropie średniowiecznych rękopisów, s. 285.

${ }^{75}$ Wisłocki, Katalog rękopisów, cz. 2, s. 599.

${ }^{76}$ Wójcik-Zega, Jan ze Skawiny, s. 146 (tutaj określony jako brat).

${ }^{77}$ Wisłocki, Katalog rękopisów, cz. 2, s. 575. Tutaj błędnie ustalony autor dzieła jako św. Tomasz z Akwinu. 
z Myślenic, proboszczowi w rodzinnej miejscowości ${ }^{78}$. Także po bracie, choć nie wiadomo dokładnie kiedy, odziedziczył zbiór zawierający pisma teologiczne, w tym Mikołaja z Błonia Tractatus sacerdotalis de sacramentis oraz instrukcję wizytacji parafialnej i kwestie polskich uczonych poświęcone różnym zagadnieniom prawnym i teologicznym (rkps 2415) ${ }^{79}$. Na zawartość czwartego rękopisu (rkps 1410) składają się dzieła o różnej treści: Jana Gobi młodszego Scala caeli, Henryka z Friemar, Super decem praecepta, Jana z Nivelle Allegationes Veteris et Novi Testamenti, Rajmunda z Peñafort, Summa de poenitentia, fragment Gesta Romanorum, fragment komentarza do trzeciej księgi Dekretatów Grzegorza IX i inne. Piotr ze Skawiny otrzymał go na mocy testamentu Jana z Pilzna (dokładnie nie wiadomo którego), po czym przekazał go Janowi ze Skawiny. Ten z kolei w 1505 roku zapisał go początkowo na rzecz domu kanoników w Krakowie, a później Stanisława $z$ Myślenic ${ }^{80}$. Nieco dłuższą drogę przebył inny rękopis o sygnaturze 2516, zawierający traktat Tomasza z Chobham Summa de poenitentia et officialis ecclesiasticis oraz omówienie zawartości drugiej ksiąg Sentencji Piotra Lombar$\mathrm{da}^{81}$. Piotr ze Skawiny przekazał go Janowi, ten zaś w 1505 roku podarował go Stanisławowi Skawince, wówczas licencjatowi teologii i prepozytowi klasztoru bożogrobców św. Jadwigi na Stradomiu ${ }^{82}$. Trudno dociec, czy obaj uczeni byli ze sobą spokrewnieni, czy jedynie zaprzyjaźnieni, niemniej jednak w 1515 roku Jan ze Skawiny nadal był w posiadaniu rękopisu, jako że w dniu 3 lipca ofiarował go Stanisławowi z Myślenic. W tym samym też roku krakowski doktor prawa sprezentował swojemu siostrzeńcowi jeszcze jeden rękopis o sygnaturze 2508 zawierający różne kolekcje kazań z XV wieku ${ }^{83}$.

W jaki sposób księgi podarowane Stanisławowi z Myślenic trafiły do biblioteki Wydziału Prawa, pozostaje nierozstrzygnięte. Możliwości jest wiele, z czego dość prawdopodobne wydają się trzy. Po pierwsze Jan ze Skawiny mógł powtórnie odzyskać wszystkie ofiarowane siostrzeńcowi kodeksy i umieścić je w księgozbiorze prawniczym. Rodzi się wówczas wątpliwość, dlaczego zatem nie zamieścił stosownych wpisów w rękopisach tak, jak czynił to w każdym innym przypadku. Druga możliwość - siostrzeniec Jana ze Skawiny z inspiracji swojego wuja mógł przekazać swoje książki na rzecz uniwersytetu w momencie, gdy nie były one mu już potrzebne lub zapisać je w testamencie. Mogło to się dokonać już po śmierci skawińskiego doktora prawa, co tłumaczyłoby brak precyzyjnej informacji o sposobie pozyskania egzemplarzy przez bibliotekę, o której zamieszczenie szczególnie dbał Jan ze Skawiny. Trzecia możliwość zakłada, że Stani-

${ }^{78}$ Catalogus, t. 1, s. 150-151 (M. Kowalczyk, Opis cod. 143); Wójcik-Zega, Jan ze Skawiny, s. 146.

${ }^{79}$ Wisłocki, Katalog rękopisów, cz. 2, s. 580.

${ }^{80}$ Catalogus, t. 9, oprac. M. Kowalczyk i in., Cracoviae 2008, s. 420-425 (M. Kowalczyk, L. Nowak, Opis cod. 1410).

${ }^{81}$ Wisłocki, Katalog rękopisów, cz. 2, s. 600.

${ }^{82}$ Zob. M. Zwiercan, Skawinka Stanistaw, w: Polski Stownik Biograficzny, t. 38, red. H. Markiewicz, Kraków 1997-1998, s. 111.

${ }^{83}$ Wisłocki, Katalog rękopisów, cz. 2, s. 598. 
sław nigdy nie odebrał książek od swojego wuja i pozostawały one w budynku Collegium Iuridicum, aż w końcu w sposób naturalny weszły w skład tamtejszej biblioteki.

Można się też zastanawiać, co skłoniło Jana ze Skawiny do ofiarowania części swoich rękopisów krewnemu, a nie bibliotece, o której powiększenie troszczył się w czasie pełnienia przez siebie funkcji bibliotekarza. Kiedy przypatrzymy się zawartości poszczególnych kodeksów, dostrzeżemy, że zawierają one dzieła o treści bardziej teologicznej niż prawniczej. Wyjątkiem może być zbiór akt z konsystorza gnieźnieńskiego z rękopisu 143 oraz kilka dzieł prawniczych z rękopisu 1410, ale nawet $\mathrm{i}$ one były bardziej użyteczne dla prawnika aktywnego na polu zawodowym niż profesora czy studenta prawa. Nie wiemy, czy Stanisław z Myślenic pełnił jakąkolwiek funkcję wymagającą od niego znajomości prawa kanonicznego, natomiast raczej na pewno nie był wykształcony w tym kierunku ${ }^{84}$. Pozostałe dzieła (z rękopisów BJ 1410, 2508, 2516) były przydatne szczególnie w pracy kaznodziejskiej i mogły faktycznie być przedmiotem zainteresowania plebana z Myślenic.

W sumie można doliczyć się dwanaście kodeksów, które stanowiły prywatną własność Jana ze Skawiny (zob. tab. 3), z których bezpośrednio do biblioteki Wydziału Prawa zostało przez niego przekazanych siedem, cztery otrzymał siostrzeniec uczonego Stanisław z Myślenic, jeden zaś pozbawiony jest jakichkolwiek wpisów sporządzonych ręką bibliotekarza. Spośród różnych funkcji, które pełnił

Tabela 3. Wlaściciele rękopisów będących własnością Jana ze Skawiny

\begin{tabular}{|c|c|c|}
\hline Sygnatura & Wlaściciele & $\begin{array}{c}\text { Data przekazania do biblioteki } \\
\text { Collegium Iuridicum }\end{array}$ \\
\hline 143 & $\begin{array}{l}\text { 1. Konsystorz gnieźnieński do ok. } 1427 \text { r. } \\
\text { 2. Konsystorz krakowski } \\
\text { 3. Maciej ze Skawiny } \\
\text { 4. Piotr ze Skawiny do } 1488 \mathrm{r} \text {. } \\
\text { 5. Jan ze Skawiny } 1488-1505 \\
\text { 6. Konsystorz krakowski [?] } \\
\text { 7. Stanisław z Myślenic }\end{array}$ & po 1505 \\
\hline 367 & $\begin{array}{l}\text { 1. Uniwersytet Praski od } 1399 \mathrm{r} \text {. } \\
\text { 2. Jan ze Skawiny po } 1475 \mathrm{r} \text {. }\end{array}$ & 1505 \\
\hline 368 & Jan ze Skawiny od 1476 r. & 1505 \\
\hline 404 & $\begin{array}{l}\text { 1. Mikołaj z Wiślicy przed } 1415 \text { r. } \\
\text { 2. Maciej z Koła przed } 1441 \mathrm{r} \text {. } \\
\text { 3. Jan Stolle z Głogowa przed } 1450 \mathrm{r} \text {. } \\
\text { 4. Jan ze Skawiny po } 1475 \mathrm{r} \text {. }\end{array}$ & 1501 \\
\hline
\end{tabular}

${ }^{84}$ Zob. Metryka, t. 1, s. 375 [74h/313], gdzie informacja jedynie o immatrykulacji na Uniwersytecie Krakowskim, natomiast brak wiadomości o uzyskaniu jakichkolwiek stopni naukowych w Księdze Promocji. 


\begin{tabular}{|c|c|c|}
\hline 407 & $\begin{array}{l}\text { 1. Tomasz Strzępiński } \\
\text { 2. Jan ze Skawiny }\end{array}$ & $\begin{array}{l}\text { 1. } 1446 \\
\text { 2. } 1509\end{array}$ \\
\hline 1410 & $\begin{array}{l}\text { 1. Jan Koczwara z Pyzdr } \\
\text { 2. Jan z Pilzna } \\
\text { 3. Piotr ze Skawiny } \\
\text { 4. Jan ze Skawiny przed } 1505 \text { r. } \\
\text { 5. Stanisław z Myślenic }\end{array}$ & po 1505 \\
\hline 2399 & $\begin{array}{l}\text { 1. Maciej z Ruśca (Ruszczy) } \\
\text { 2. Piotr ze Skawiny do } 1488 \text { r. } \\
\text { 3. Jan ze Skawiny od } 1488 \text { r. }\end{array}$ & - \\
\hline 2415 & $\begin{array}{l}\text { 1. Jakub Grzymała } \\
\text { 2. Piotr ze Skawiny } \\
\text { 3. Jan ze Skawiny }\end{array}$ & - \\
\hline 2508 & $\begin{array}{l}\text { 1. Maciej z Opola } \\
\text { 2. Jan ze Skawiny do } 1515 \text { r. } \\
\text { 3. Stanisław z Myślenic od } 1515 \text { r. }\end{array}$ & po 1515 \\
\hline 2513 & $\begin{array}{l}\text { 1. Marcin z Holeszowa przed } 1440 \mathrm{r} \text {. } \\
\text { 2. Bursa Ubogich [?] } \\
\text { 3. Jan ze Skawiny }\end{array}$ & 1515 \\
\hline 2516 & $\begin{array}{l}\text { 1. Piotr ze Skawiny } \\
\text { 2. Jan ze Skawiny } \\
\text { 3. Stanisław Skawinka od } 1505 \mathrm{r} \text {. } \\
\text { 4. ponownie Jan ze Skawiny do } 1515 \mathrm{r} \text {. } \\
\text { 5. Stanisław z Myślenic od } 1515 \mathrm{r} \text {. }\end{array}$ & po 1515 \\
\hline 3257 & $\begin{array}{l}\text { 1. Paweł ze Służewa } \\
\text { 2. Jan ze Skawiny }\end{array}$ & - \\
\hline
\end{tabular}

Źródło: Badania własne.

\section{Podsumowanie}

Zdecydowana większość bibliotekarzy na Wydziale Prawa pozostaje anonimowa. Ich nazwiska nigdzie nie zostały zapisane, rzadko też wymieniani byli w źródłach z funkcją opiekuna książek (custos, pater librorum). Większość profesorów będących bibliotekarzami nie zabiegała zbytnio o zapisanie się w dziejach uniwersytetu w roli kustoszy księgozbiorów, a ich obowiązki biblioteczne traktowane były jako służba honorowa ${ }^{85}$, choć zapewne nieraz i też jako dodatkowe obciążenie. Na tym tle aktywność Jana ze Skawiny stanowi wyjątek. Nie tylko pozostawił on ślad po swojej wieloletniej działalności bibliotecznej w postaci wpisów proweniencyjnych, ale też z dumą pisał o sobie „librarista” (zob. il. 1).

\footnotetext{
${ }^{85}$ Zathey, Biblioteka Jagiellońska, s. 24-25.
} 


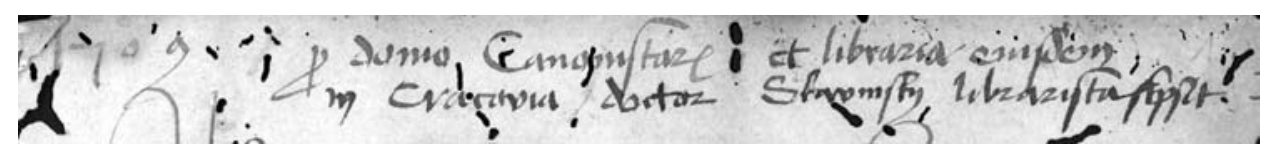

Il. 1. Nota Jana ze Skawiny, w której pisze o sobie jako bibliotekarzu

(Źródło: Biblioteka Jagiellońska, rkps 407, k. IIr.).

w tamtym czasie, właśnie ta wydała mu się najistotniejsza w kontekście ofiarowania rękopisu do biblioteki. Możliwe też, że Jan ze Skawiny w sposób świadomy „przemycił” swój życiorys poprzez zamieszczanie w różnych rękopisach informacji, które wzajemnie się dopełniają, o uzyskanych stopniach naukowych oraz pełnionych urzędach, niekiedy też $\mathrm{z}$ datami ${ }^{86}$. Niezależnie jednak od intencji autora faktem pozostaje, że w pamięci uniwersyteckiej najbardziej został zapamiętany jako bibliotekarz księgozbioru Wydziału Prawa, który nie uchylał się od przyjmowania na siebie obowiązku dbania o zbiory, a wręcz przeciwnie - chętnie podejmował się powierzonej mu funkcji. Niestety fragmentaryczność zachowanych źródeł nie pozwala na dokładne prześledzenie codziennych jego czynności bibliotecznych, a więc, czy prowadził rejestry wypożyczeń i zwrotów, czy obiekty utrzymywał w należytym porządku i jak często był przystępny dla osób chcących skorzystać z czytelni. Najważniejszymi jego dokonaniami na tym polu było natomiast rzetelne oznaczenie rękopisów, które wchodziły w skład biblioteki, w niektórych z nich zamieszczenie informacji o donatorach lub właścicielach kodeksów, a niekiedy także o roku przekazania obiektu na rzecz społeczności Collegium Iuridicum. Będąc kustoszem księgozbioru, zabiegał o powiększenie jego zasobu poprzez pozyskiwanie darów książkowych od profesorów, a przede wszystkim ofiarowanie swoich egzemplarzy dzieł, które jego zdaniem mogły szczególnie być przydatne wykładowcom i studentom prawa. Obok Arnolfa z Mierzeńca stał się jednym z najhojniejszych darczyńców biblioteki Wydziału Prawa. Jan ze Skawiny jako bibliotekarz niewątpliwie był kimś więcej aniżeli tylko opiekunem książek. Jego działalność ukazuje go jako intelektualistę świadomego wartości dzieła pisanego w procesie nauczania oraz odpowiednio doceniającego znaczenie książki jako nośnika wiedzy dla kolejnych pokoleń czytelników. 


\section{BIBLIOGRAFIA}

\section{Źródla}

Biblioteka Jagiellońska (BJ)

sygn. 143, 248, 293, 327, 333, 342, 344, 345, 367, 368, 378, 403, 404, 407, 471, 1184 , $1214,1229,1242,1246,1291,1295,1301,1344,1410,1442,1595,1603,1609$, 1624, 1629, 1742, 2371, 2389, 2392, 2398, 2399, 2400, 2401, 2402, 2415, 2416, $2508,2513,2515,2516,2537,3257$

Acta rectoralia Almae Universitatis studii Cracoviensis inde ab anno MCCCCLXIX, ed. W. Wisłocki, Cracoviae 1894.

Codex diplomaticus Universitatis Studii Generalis Cracoviensis, t. 1, Cracoviae 1870.

Metryka Uniwersytetu Krakowskiego z lat 1400-1508, wyd. A. Gąsiorowski, T. Jurek, I. Skierska, przy współpr. R. Grzesika, Kraków 2004.

Najstarsza księga promocji Wydziału Sztuk Uniwersytetu Krakowskiego z lat 1402-1541, wyd. A. Gąsiorowski, T. Jurek, I. Skierska, Warszawa 2011.

Statuta antiqua Collegii Majoris, wyd. J. Szujski, w: Archiwum do Dziejów Literatury i Oświaty w Polsce, Seria I, t. 1, Kraków 1878, s. 1-20.

Wypisy źródłowe do dziejów Wawelu 1440-1500, opr. B. Przybyszewski, Kraków 1960.

\section{Opracowania}

Bandtkie Jerzy S., Historya Biblioteki Uniwersytetu Jagiellońskiego w Krakowie, Kraków 1821.

Bartel Wojciech M., Dzieje Wydziału Prawa Uniwersytetu Jagiellońskiego przed reforma Kottątajowska (Próba zarysu), „Krakowskie Studia Prawnicze”, 3 (1970) s. 159-213.

Barycz Henryk, Historia Uniwersytetu Jagiellońskiego w epoce Humanizmu, Kraków 1935.

Barycz Henryk, Polacy na studiach w Rzymie w epoce Odrodzenia (1440-1600), Kraków 1938.

Catalogus codicum manuscriptorum medii aevi Latinorum qui in Bibliotheca Jagellonica Cracoviae asservantur, t. 1-10, Wratislaviae-Varsaviae-Cracoviae-Gedani 19802012.

Ehrlich Ludwik, Z dziejów Wydziału Prawa UJ w wieku XV, w: Studia z dziejów Wydziału Prawa Uniwersytetu Jagiellońskiego, red. M. Patkaniowski, Kraków 1964 („Zeszyty Naukowe Uniwersytetu Jagiellońskiego. Prace Prawnicze”, z. 18), s. 35-48.

Galos Małgorzata, Kubic Żaneta, Biblioteka Jagiellońska w latach 1775-1835, w: Historia Biblioteki Jagiellońskiej, t. 2: 1775-1918, red. P. Lechowski, Kraków 2017, s. 27-158.

Hajdukiewicz Leszek, Księgozbiór i zainteresowania bibliofilskie Piotra Tomickiego na tle jego działalności kulturalnej, Wrocław 1961 („Monografie z Dziejów Nauki i Techniki", t. 18).

Inkunabuły Biblioteki Jagiellońskiej, oprac. A. Lewicka-Kamińska, Kraków 1962.

Katalog poloników XVI wieku Biblioteki Jagiellońskiej, t. 3: Indeksy, red. M. Malicki, E. Zwinogrodzka, oprac. M. Gołuszka i in., Kraków 1995.

Knoll Paul W., "A Pearl of Powerful Learning”. The University of Cracow in the Fifteenth Century, Leiden-Boston 2016.

Kowalska-Urbankowa Zofia, Zbudniewek Janusz ZP, Katalog rękopisów biblioteki paulinów w Krakowie na Skatce, ,Studia Claromontana”, 8 (1987) s. 269-500.

Kozłowska-Budkowa Zofia, Odnowienie jagiellońskie Uniwersytetu Krakowskiego (1390-1414), w: Dzieje Uniwersytetu Jagiellońskiego w latach 1364-1764, t. 1, red. K. Lepszy, Kraków 1964, s. 37-87. 
Kurtyka Janusz, Leńcze, w: Słownik historyczno-geograficzny województwa krakowskiego w średniowieczu, cz. 3, red. F. Sikora, Kraków 2000, s. 528-547.

Lewicka-Kamińska Anna, Biblioteka Jagiellońska w latach 1492-1655, w: Historia Biblioteki Jagiellońskiej, t. 1: 1364-1775, red. I. Zarębski, Kraków 1966, s. 131-271.

Malinowska-Kwiatkowska Irena, I manoscritti giuridici Bolognesi al Collegium Iuridicum dell' Università Jagellonica (il lascito di Piotr Wolfram), w: Laudatio Bononiae. Atti del Convegno storico italo-polacco svoltosi a Bologna dal 26 al 31 maggio 1988 in occasione del Nono Centenario dell' 'Alma Mater Studiosorum', red. R.C. Lewanski, Varsavia 1990, s. 161-166.

Sobańska Anna, List o pożarze Krakowa w roku 1455 z rękopisu Mikołaja Byliny, „Studia Mediewistyczne", 31 (1994), s. 127-131.

Szelińska Wacława, Biblioteki profesorów Uniwersytetu Krakowskiego w XV i poczatkach XVI wieku, Wrocław-Warszawa-Kraków 1966.

Szyma Marcin, Gmach kolegium prawniczego i Dom Kanoniczny do końca epoki nowozytnej, w: S.A. Sroka i in., Collegium Iuridicum, Kraków 2015, s. 35-51.

Świeboda Wojciech, Na tropie średniowiecznych rękopisów Wydziału Prawa Uniwersytetu Krakowskiego, w: Felix indiget amicis. Studia z dziejów kultury duchowej i intelektualnej średniowiecza ofiarowane Profesorowi Krzysztofowi Ożogowi, red. W. Świeboda, M. Zdanek, Kraków 2016, s. 277-317.

Wisłocki Władysław, Katalog rękopisów Biblijoteki Uniwersytetu Jagiellońskiego, Kraków 1877-1881.

Włodarek Andrzej, Architektura średniowiecznych kolegiów i burs Uniwersytetu Krakowskiego, Kraków 2000.

Wójcik-Zega Dagmara, Jan ze Skawiny, w: Profesorowie Wydziału Prawa Uniwersytetu Jagiellońskiego, t. 1: 1364-1780, red. W. Uruszczak, Kraków 2015, s. 146-148.

Zathey Jerzy, Biblioteka Jagiellońska w latach 1364-1492, w: Historia Biblioteki Jagiellońskiej, t. 1: 1364-1775, red. I. Zarębski, Kraków 1966, s. 1-130.

Zawadzki Roman, Spuścizna pisarska Stanisława ze Skarbimierza. Studium źródłoznawcze, Kraków 1979.

Zdanek Maciej, Arnolf z Mierzeńca, w: Profesorowie Wydziału Prawa Uniwersytetu Jagiellońskiego, t. 1: 1364-1780, red. W. Uruszczak, Kraków 2015, s. 18-19.

Zdanek Maciej, Bartłomiej ze Żnina, w: Profesorowie Wydziału Prawa Uniwersytetu Jagiellońskiego, t. 1: 1364-1780, red. W. Uruszczak, Kraków 2015, s. 22-23.

Zwiercan Marian, Skawinka Stanisław, w: Polski Słownik Biograficzny, t. 38, red. H. Markiewicz Kraków 1997-1998, s. 111. 


\section{'EGO LIBRARISTA'. THE ACTIVITY OF JAN OF SKAWINA AS A LIBRARIAN AT THE FACULTY OF LAW OF THE UNIVERSITY OF KRAKÓW}

\section{Summary}

The article is devoted to the figure of Jan of Skawina ( $† 1520)$, a doctor and professor of canon law, librarian of the Faculty of Law of the University of Krakow. Although he was not one of the leading or distinguished figures from among the group of Polish scholars at the turn of the 15th and 16th centuries and his scientific legacy has not been preserved, he nevertheless showed particular zeal, as the guardian of the library book collection, for the other professors who held the position of librarian. Between 1501 and 1515 he obtained and systematized many works on the subject of law or preaching for the benefit of the faculty library, which were intended as aids to professors and law students. In retrospect, an invaluable achievement of the scholar from Kraków was inserting notes indicating that the manuscripts belonged to the collection of the Law College. These notes not only allow the codes to be assigned unambiguously to the Collegium Iuridicum library, but also inform about the previous owners and about the method and date of obtaining a given copy. Out of 46 preserved medieval books of the Faculty of Law, 39 have notes inscribed by his hand.

Jan of Skawina was not only a book keeper but also a donor of several manuscripts. Owing to his efforts, several professors of law and members of Jan's family passed on their books in their will to the Faculty of Law. In the face of the tragic fire of the Collegium Iuridicum building in 1455, Jan of Skawina's efforts to acquire new works facilitated a partial reconstruction of the jurist library. These were mainly legal and theological works, which could serve as an aid to the work of preaching. A casual review of the works in the book collection of the Faculty of Law allows us to conclude that the selection of the letters obtained or offered by Jan of Skawina was not accidental.

Seemingly modest testimonies of Jan of Skawina's activity as a librarian turn out to be invaluable for learning about the resources and organization of the library of the Law College. The notes he has included in his manuscripts are a very important source of information about the medieval Faculty of Law of the University of Kraków. They also prove that the position of librarian did not have to be treated by university professors as a burden, but could be seen as a kind of distinction. Jan of Skawina held a number of important church and university posts, and yet he wrote about himself modestly, but with pride, using the term 'librarista'.

Keywords: Jan of Skawina; the University of Kraków; Faculty of Law; library; medieval manuscripts 